\title{
THE EFFECT OF EARNING PER SHARE AND RETURN ON EQUITY ON STOCK PRICE (STUDY ON LISTED BANKS)
}

\author{
Hendra Hongkong ${ }^{1}$ \\ ${ }^{1}$ Alumni of Accounting Program, Economics and Business Faculty, Sam Ratulangi University, Jl. Kampus \\ Bahu, Manado, 95115, Indonesia \\ Corresponding e-mail : hendrahongkong@gmail.com
}

\begin{abstract}
Banking is an important industry in supporting the overall development financing program both as a fundraiser, as an investment and working capital financing institution as well as an institution that channel funds to people who are underfunded. Stock prices are important for investors because they will determine the amount of investor wealth. Investors are willing to buy shares at a certain price if they get more benefits or results than the sacrifices they have made. The data of the sample drawn from financial statements in period of 2006 to 2009 which make total observed data is 40. This study finds that partially EPS and ROE variables affect stock prices which can be seen in the results of the t test.
\end{abstract}

Keywords : earnings per share, return on equity, stock prices

\section{INTRODUCTION}

The capital market has a big role for the economy of a country because the capital market runs two functions, namely the function of the economy and financial functions. The capital market has an economic function because the capital market provides facilities that bring together two interests, namely those with excess funds and those who need funds. The capital market has a financial function because the capital market provides the possibility and opportunity to obtain benefits for the owner of the fund, according to the characteristics of the chosen investment. The capital market can also be said as a forum that can eliminate the monopoly of the source of capital and the monopoly of ownership of the company because the capital market is a means for companies to be able to go public and then holders of securities also become owners of the company so that the company becomes public property.

Banking is an important industry in supporting the overall development financing program both as a fundraiser, as an investment and working capital financing institution as well as an institution that channel funds to people who are underfunded. Banks as institutions of public trust and part of the monetary system have a strategic position to support economic development. Therefore, the government has set requirements or conditions for the banking industry since its founding permit, requirements for prospective managers and operational provisions based on the principle of prudence (prudential regulation) in conducting bank business activities. The capital market situation is a step for investors to decide to buy shares. Information in the capital market influences investor confidence that shapes the efficiency of the capital market. The increase and decrease in transaction volume and the stock price index indicate investor confidence in conducting transactions in the capital market. Companies that have stable stock prices and tend to increase are important for the company because of course it will encourage the interest of prospective investors to invest in the company.

Stock prices are important for investors because they will determine the amount of investor wealth. Investors are willing to buy shares at a certain price if they get more benefits or results than the sacrifices they have made. For this reason, a number of information related to stock prices is needed to be able to make decisions about stocks that are worthy of being chosen. Many factors influence changes in stock prices, both from internal companies and 
from external companies. The company's conditions reflected in the company's financial statements, namely in the form of balance sheets, profit and loss, company cash flows and other supporting reports are internal factors. And the condition of this company is one of the considerations for investors to invest their capital. Political conditions, economic conditions, and industry are external factors which also greatly affect stock prices.

\section{LITERATURE REVIEW}

Earnings per share (EPS) information of a company shows the size of the company's net profit that is ready to be shared with all company shareholders. The amount of EPS of a company can be known from the company's financial statement information. Although not all companies include the amount of EPS, the amount of EPS can be calculated based on the balance sheet and corporate income statement. Earnings per share (EPS) shares are obtained from the financial statements presented by the company. Therefore the first step taken is to understand the financial statements presented by the company.

There are two main financial statements, namely balance sheet and income statement. Some studies show that EPS contains information that is useful for making predictions about future stock prices. Tarore dan Pontoh (2010), Indira and Dwiastutiningsih (2015), Utami and Darmawan (2018), and Agnatia and Amalia (2018) find that profitability has significant and positive to share prices. More specific, Suaryana (2013), and Munggaran et al. (2017) find that earnings per share has significant effect to share price.

Return on equity (ROE) is one of the main tools of investors that are most often used in valuing a stock. In its calculations, ROE is generally generated from the distribution of profits with equity over the past year. Although the method of calculating it is very easy but by understanding in depth ROE can provide an overview of three main things, namely: (1) the company's ability to generate profits (profitability); (2) company efficiency in managing assets (assets management); and (3) debt used in doing business (financial leverage). Lumowa (2015), Kristanti and Sutono (2016), Putra and Lestari (2016), Johan and Septariani (2017), Hikmah. (2018), and Utomo (2019) show that return on equity (ROE) has positive and significant effect on share price.

Ha: profitability affects the value of stock prices on banks listed on the Indonesia Stock Exchange.

\section{RESEARCH METHOD}

The population of this study is that all public banks and are listed on the Indonesia Stock Exchange which make the sample of this study are 10 banks. The data of the sample drawn from financial statements in period of 2006 to 2009 which make total observed data is 40. The independent variable in this study is earnings per share which is the ratio between earnings after tax and the number of shares outstanding which shows net income per share in 2006 - 2009 and return on equity which is the ratio of net income to equity in ordinary shares or return on investment shareholders. The dependent variable is stock prices, namely the last price reported by securities sold on the stock and expressed in units of IDR. This study conducts multiple regressions as method of analysis with equation note as follows.

Price $=\alpha+\beta_{1}$ EPS $+\beta_{2}$ ROE

\section{RESULT AND DISCUSSION}

\subsection{Results}

Table 1 shows that bank that reached the highest EPS level was Bank Rakyat Indonesia. TBK in 2006 amounted to $346.53 \%$ and in 2009 amounted to $592.73 \%$, which indicated that BRI had good financial performance because it had a large net income, while 
the lowest EPS is ICB Bumiputera Tbk which only ranged from $1.59 \%$ to $4.13 \%$ during 2006 to 2009.

Table 1. Earnings per share

\begin{tabular}{lcccc}
\hline \multirow{2}{*}{ Bank } & \multicolumn{6}{l}{ Earnings per share } & & \\
\cline { 2 - 5 } & $\mathbf{2 0 0 6}$ & $\mathbf{2 0 0 7}$ & $\mathbf{2 0 0 8}$ & $\mathbf{2 0 0 9}$ \\
\hline Mandiri & 117.37 & 209.46 & 88.55 & 19.26 \\
BNI & 145 & 58.79 & 80.04 & 162.63 \\
BRI & 346.53 & 392.77 & 483.43 & 592.73 \\
Danamon & 267.97 & 420.6 & 303.21 & 182.65 \\
BCA & 344.16 & 364.17 & 234.28 & 276.1 \\
Permata & 40.23 & 64.45 & 58.43 & 62.01 \\
Pan Indonesia & 32.47 & 42.17 & 34.49 & 38 \\
ICB Bumiputera & 1.59 & 4.13 & 0.39 & 1.01 \\
Niaga & 53.69 & 62.53 & 28.33 & 65.52 \\
NISP & 48.02 & 43.01 & 54.5 & 74.96 \\
\hline
\end{tabular}

Rentability of own capital in this case is the return on equity equity commonly used to measure the level of profit generated from shareholder investment. Investors perceive that $\mathrm{ROE}$ is an important indicator of profitability, because ROE is an indicator to measure management success in order to carry out its duties of generating maximum profits for capital owners. The following is the ROE data of 10 banks that are the object of research. Table 2 shows that BRI banks have the highest average ROE growth during 2006 - 2009, which ranged from $34.99-40.03 \%$, this indicates that BRI banks have high net income, increasing the ROE percentage.

Table 2. Return on equity

\begin{tabular}{lllll}
\hline \multirow{2}{*}{ Bank } & \multicolumn{4}{l}{ Return on equity } \\
\cline { 2 - 5 } & $\mathbf{2 0 0 6}$ & $\mathbf{2 0 0 7}$ & $\mathbf{2 0 0 8}$ & $\mathbf{2 0 0 9}$ \\
\hline Mandiri & 10.75 & 21.66 & 26.44 & 30.83 \\
BNI & 19.19 & 8.6 & 12.52 & 17.99 \\
BRI & 34.99 & 40.03 & 39.46 & 36.29 \\
Danamon & 22.28 & 30.59 & 25.31 & 15 \\
BCA & 33.58 & 31.32 & 33.16 & 32.11 \\
Permata & 12.1 & 18.88 & 17.6 & 15.85 \\
Pan Indonesia & 15.76 & 17.46 & 14.54 & 13.09 \\
ICB Bumiputera & 2.43 & 6.1 & 1.16 & 2.1 \\
Niaga & 19.46 & 19.74 & 11.66 & 19.32 \\
NISP & 13.56 & 10.45 & 12.51 & 14.8 \\
\hline
\end{tabular}

The stock price that applies every day is always changing, up or down. The stock price data obtained in this study also fluctuates. But the stock price used in this study is the closing price and the list of 10 bank stock prices. Table 3 shows the stock price data obtained from the financial statements during the period of 2006 to 2009, BRI banks have the highest share price, which ranges from Rp.5150 to Rp.7650. While the bank danamon ranked second highest share price, which fluctuated between Rp.4550 to Rp.6046, while the lowest share price was ICB Bumiputera which was only in the range of Rp. 90 to Rp. 120. 
Table 3. Share price

\begin{tabular}{|c|c|c|c|c|}
\hline \multirow{2}{*}{ Bank } & \multicolumn{4}{|c|}{ Share price } \\
\hline & 2006 & 2007 & 2008 & 2009 \\
\hline Mandiri & 2900 & 3500 & 2025 & 4700 \\
\hline $\mathrm{BNI}$ & 1843 & 1970 & 680 & 1980 \\
\hline BRI & 5150 & 7400 & 4575 & 7650 \\
\hline Danamon & 5102 & 6046 & 2343 & 4550 \\
\hline BCA & 2600 & 3650 & 3250 & 4850 \\
\hline Permata & 870 & 890 & 490 & 800 \\
\hline Pan Indonesia & 580 & 680 & 580 & 760 \\
\hline ICB Bumiputera & 90 & 131 & 62 & 120 \\
\hline Niaga & 920 & 900 & 495 & 710 \\
\hline NISP & 834 & 900 & 700 & 1000 \\
\hline
\end{tabular}

Table 4 presents the result of multiple regressions of EPS and ROE on share price. The results show that the EPS and ROE have significant and positive on share price partially. The correlation $(\mathrm{R})$ between the independent variable and the dependent variable is between EPS and ROE and the stock price is 0.827 so it can be concluded that there is a very strong relationship between the independent variable and the dependent variable. Also, the $\mathrm{R}$ square shows that the contribution of independent variables to explain the model of dependent variable is 0.684 or $68.4 \%$ and the remainder is explained by other factors which are not included in this study.

Table 4. Multiple regression result of EPS and ROE on share price

\begin{tabular}{ll}
\hline Independent variables & Coefficients \\
\hline Constant & 376.383 \\
EPS & $7.831^{*}$ \\
ROE & $92.996^{* *}$ \\
R & 0.827 \\
R square & 0.684 \\
\hline
\end{tabular}

Notes: Dependent variable is share price. EPS is earnings per share, ROE is return on equity. ${ }^{*}$ and $* *$ are significant at 0.01 and 0.05 respectively

\subsection{Discussions}

In stock investment decision making there are many factors that need to be considered both internal and external factors that can be analyzed technically or fundamentally in this study. The research variable is limited to accounting variables only in the form of analysis of EPS and ROE which are considered to greatly influence stock investment decisions. Based on the results of the research and data processing conducted on the effect of EPS and ROE on the stock price of the 10 banks listed on the Stock Exchange, the EPS and ROE have an effect on stock prices. The amount of the contribution of EPS and ROE variables to stock prices is 0.684 or $68.4 \%$ while the rest is explained by other factors not included in this study. Based on the results of hypothesis testing it was found that partially EPS and ROE variables had an effect on stock prices.

Those results are consistent with studies by Tarore dan Pontoh (2010), Indira and Dwiastutiningsih (2015), Utami and Darmawan (2018), and Agnatia and Amalia (2018). The results of this study also support the studies of Suaryana (2013), and Munggaran et al. (2017) who find that earnings per share has significant effect to share price. Moreover, this study also supports the studies of Lumowa (2015), Kristanti and Sutono (2016), Putra and Lestari (2016), Johan and Septariani (2017), Hikmah (2018), and Utomo (2019) who show that return 
on equity (ROE) is positive and has significant effect on share price. Normally, EPS is used to find out company profits that will be shared with shareholders so that investors get an idea of the results of their future investments, while by analyzing ROE investors can find out the amount of income earned from capital investment, therefore investors tend to use EPS and $\mathrm{ROE}$ for decision making in stock investments in addition to other financial factors or ratios.

\section{CONCLUSION}

BRI Bank is the bank that has the highest EPS and ROE figures throughout 20062009. Every increase in EPS and ROE will result in an increase in stock prices. Partially EPS and ROE variables affect stock prices which can be seen in the results of the test. The contribution of independent variables to the dependent variable is $68.4 \%$ while the rest is explained by other variables. For investors, the authors suggest looking at other fundamental factors in addition to financial ratios, such as inflation rates, interest rates, government political policies, security levels, and government regulations and market sentiment in order to obtain a more accurate analysis of stock price changes. For companies, companies should better improve the company's financial performance so that EPS can be obtained high and the company is able to increase profits. Because according to this study EPS and ROE have a positive effect on stock prices in this industry. With the increasing EPS and ROE more and more investors are interested in investing so that they can increase stock prices. To further refine the research that has been done, the author also provides suggestions that can be used for further research. Research can use a larger amount of data, in a longer period of time and can be carried out on various other industry sectors on the Indonesia Stock Exchange in order to provide better results.

\section{DAFTAR PUSTAKA}

Agnatia, V., \& Amalia, D. (2018). Pengaruh Economic Value Added (EVA) dan rasio profitabilitas terhadap harga saham. Journal Of Applied Managerial Accounting, 2(2), 290-303. https://doi.org/10.30871/jama.v2i2.900

Hikmah. (2018). Pengaruh rasio profitabilitas terhadap harga saham perusahaan sub sektor minyak dan gas bumi yang terdaftar di BEI, Journal Management \& Business, 2(1). https://doi.org/10.6234/sejaman.v2i1.334

I G.N.A. Suaryana, P. (2013). Pengaruh EPS, DER, dan PBV terhadap harga saham. E-Jurnal Akuntansi, , 215-229.

Indira, C., \& Dwiastutiningsih, R. (2015). Pengaruh faktor-faktor fundamental terhadap harga saham PT. Unilever Indonesia Tbk tahun 2004-2013. Journal of Business Economics, 19(3). doi:http://dx.doi.org/10.35760/eb.2014.v19i3.1163

Johan, R. S., \& Septariani, D. (2017). Journal of Applied Business and Economics, 3(3), 126138

Kristanti, N., \& Sutono. (2016). Pengaruh earning per share, return on equity dan debt to equity ratio terhadap harga saham pada perusahaan food and beverages yang terdaftar di Bursa Efek Indonesia. Dharma Ekonomi, 23(44), 65-73.

Lumowa, D. (2015). Analisa pengaruh profitabilitas terhadap harga saham perusahaan LQ 45 di Bursa Efek Indonesia. ACCOUNTABILITY, 4(2), 72-86. https://doi.org/10.32400/ja.10526.4.2.2015.72-86

Munggaran, A., Mukaram, \& Sarah, I. S. (2017). Pengaruh Earning Per Share (EPS) terhadap harga saham. Jurnal Riset Bisnis \& Investasi, 3(2). 
Putra, B. M., \& Lestari, H. S. (2016). Pengaruh kebijakan dividen terhadap kekayaan pemegang saham pada perusahaan manufaktur yang terdaftar di Bursa Efek Indonesia. Jurnal Penelitian dan Karya Ilmiah Lemlit, 1(2), 121-131.

Tarore, W., \& Pontoh, W. (2010). Analisis pengaruh devidend per share dan earning per share terhadap harga saham pada perusahaan go public di Bursa Efek Indonesia. Jurnal Riset Akuntansi Going Concern, 5.

Utami, M., \& Darmawan, A. (2018). Pengaruh DER, ROA, ROE, EPS dan MVA terhadap harga saham pada indeks saham syariah Indonesia. Journal of Applied Managerial Accounting, 2(2), 206-218. https://doi.org/10.30871/jama.v2i2.910

Utomo, A. S. (2019). Pengaruh CSR, ROI, ROE terhadap harga saham pada perusahaan manufaktur yang terdaftar di Bursa Efek Indonesia. Jurnal PETA, 4(1), 82-94. 